\title{
Heavy metal gradients from rural to urban lakes in central China
}

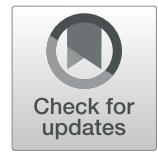

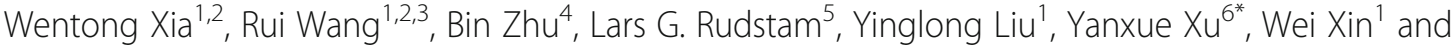 \\ Yushun Chen ${ }^{1,2^{*}}$
}

\begin{abstract}
Background: Limited information is available on heavy metal patterns in lakes under rapid watershed urbanization, especially considering a large spatial gradient with a long linear distance and great variations in topographic relief. To fill this gap, we studied concentrations of a series of heavy metals in both water and sediments from 20 lakes along a rural to urban gradient in central China, and we aimed to understand the effects of urban processes on heavy metal dynamics in lake ecosystems. Studied lakes were divided into five groups: A (rural reservoir group), B (rural commercial fishing group), C (urban park group), D (urban recreational fishing group), and E (urban commercial fishing group). An inductively coupled plasma optical emission spectrometer (ICP-OES) and an inductively coupled plasma-mass spectrometer (ICP-MS) were used to analyze the heavy metals in water and sediments.
\end{abstract}

Results: An increasing trend of most heavy metals in water from rural to urban lakes was observed. Concentrations of cadmium (Cd), cobalt (Co), lead (Pb), chromium (Cr), arsenic (As), nickel (Ni), magnesium (Mn), iron (Fe), and aluminum (Al) in water were significantly lower in rural group A than those in other groups. Arsenic in sediments of rural group A was lower than those in other groups. No other heavy metal element in sediments was significantly different among groups. The enrichment factor analysis of selected heavy metals showed there were different degrees of enrichments of heavy metals in sediments. The potential ecological risk index showed a low level for heavy metals in sediments of all studied lakes.

Conclusions: Results indicated that urban processes could have an impact on heavy metals in lake water. The sources of heavy metals in sediments were more likely from anthropogenic activities. These results could enhance our understanding of metal dynamics in lake ecosystems under urbanization and could help prevent heavy metal pollutions and promote sustainable management of urban ecosystems.

Keywords: Lakes, Water, Sediment, Heavy metals, Rural to urban gradient, Urbanization

\section{Background}

Lakes play a key role in regulating climate and maintaining regional hydrological cycles and aquatic biodiversity (Wetzel 2001). Many lakes are open systems and therefore water quality in lakes can reflect the environmental

\footnotetext{
*Correspondence: xuyx@caep.org.cn; yushunchen@ihb.ac.cn

${ }^{6}$ Water Environment Institute, Chinese Academy of Environmental Planning, Beijing 100012, China

'State Key Laboratory of Freshwater Ecology and Biotechnology, Institute of Hydrobiology, Chinese Academy of Sciences, Wuhan 430072, China Full list of author information is available at the end of the article
}

changes in the surrounding area (Song et al. 2017; Xia et al. 2018; Guo et al. 2020). The middle reach of the Yangtze River Basin has many tributaries and lakes. For instance, Hubei Province in this region is known as "the province with a thousand lakes". Over the past 50 years, increased population and rapid socio-economic development have had profound impacts on these lakes. Take Wuhan City (the capital of Hubei Province) as an example, the total area of lakes decreased from $983.29 \mathrm{~km}^{2}$ in 1973 to $647.47 \mathrm{~km}^{2}$ in 2013 , with $34 \%$ reduction in area and nearly 100 lakes disappeared in the past 40 
years (Chen et al. 2015). Currently, about 38 lakes located in the central urban area are also under the risk of shrinking or being filled in (Chen et al. 2015). Previous study indicated that the loss of lakes in Wuhan is closely related to reclamation for aquaculture, agriculture, housing, commercial facilities, and other urban-related activities occurring as part of the urbanization process (Zhang et al. 2018).

Like many other large cities in China, Wuhan has been experiencing a rapid urbanization in recent years. During 2014-2018, the permanent resident population in Wuhan increased from 10.3 million to 11.1 million, and the GDP (gross domestic product) increased from 1.0 trillion yuan to 1.5 trillion yuan. During this period, the area covered by commercial buildings and housing in Wuhan increased 140 million $\mathrm{m}^{2}$ (Wuhan Bureau of Statistics 2014-2018).

Rapid urbanization affects lakes ( $\mathrm{Li}$ et al. 2013; Guo et al. 2020). Urban runoff typically contains a variety of pollutants that could degrade water quality, and related physical and chemical alterations could restructure biotic communities and reduce diversity and productivity of invertebrates and fishes in aquatic ecosystem (Wang et al. 2001; Valtanen et al. 2014; Grigas et al. 2015; Zhu et al. 2018). Another major factor is increased heavy metal pollution. Heavy metals in water are a global concern due to their bioaccumulation, environmental hazards, and persistence (Goretti et al. 2016; Chowdhury et al. 2016). Heavy metals are released into lakes and other water bodies as a consequence of rapid population growth and anthropogenic activities, such as poorly treated industrial and domestic sewage and intensified agricultural runoff (Bhuiyan et al. 2011; Islam et al. 2015; Yang et al. 2017). Industrial activities, for example electroplating, metal smelting, burning of fossil fuels, and chemical industry wastewater can release heavy metals such as $\mathrm{As}, \mathrm{Cu}$, and $\mathrm{Pb}$ (Bissen and Frimmel 2003; Zhang et al. 2016; Noli and Tsamos 2016). Urban stormwater and runoff also bring large amounts of heavy metals into receiving water bodies (Graves et al. 2004; Valtanen et al. 2014; Ferreira et al. 2016).

Heavy metals are discharged into water by natural weathering, erosion, and anthropogenic activities (Bing et al. 2016; Guo et al. 2020) and typically end up in the sediments (Scheibye et al. 2014; Guo and Yang 2016). Natural inputs include complex geological and pedological processes, soil and rock natural weathering, and atmospheric deposition (Garrett 2000; Hao et al. 2013). Anthropogenic sources include domestic sewage, industry wastewater, urban and agriculture runoff, and coal and fossil fuel combustion (Priadi et al. 2011; Li et al. 2012; Wu et al. 2017).

Previous studies related to heavy metals have focused on industries, such as mining, agriculture such as irrigation of agricultural lands with sewage, and aquaculture (e.g., Rattan et al. 2005; Noli and Tsamos 2016; Xia et al. 2018). There are some studies that reported heavy metal pollution in some typical urban lakes (e.g., Li et al. 2013; Yang et al. 2017). However, little information is available on potential heavy metal pollution in lakes that are under rapid watershed urbanization, especially considering a large spatial gradient with a long linear distance and great variations in topographic relief. To fill this gap, we selected a total of 20 lakes along a rural to urban gradient in Wuhan, the largest metropolitan area in the middle reach of the Yangtze River Basin, China. Our research questions included: (1) were heavy metals in water different among the lakes along the rural to urban gradient? and (2) were heavy metals in sediments different among lakes along the rural to urban gradient? We hypothesized that urban lakes would have higher concentrations of heavy metals in both water and sediments. Results from this study improve our understanding of the effects of urban processes on heavy metal dynamics in lake ecosystems.

\section{Materials and methods}

Study site and lake groups

A total of 20 lakes along a rural to urban gradient in Wuhan, China, were selected as study sites (Fig. 1, Table $1)$. Wuhan is the largest city in central China, with a total area of $8494 \mathrm{~km}^{2}$ and a population over 11 million (Wuhan Bureau of Statistics 2014-2018). According to the rural to urban gradient and their main service functions, these lakes were divided into five groups: (1) group A $(n=4)$ or rural reservoir group (average area $=262.5$ ha, average depth $=12.7 \mathrm{~m}$ ) is mainly natural reservoirs, used as backup drinking water sources and for irrigation. These lakes were stocked with about $90 \mathrm{~kg} / \mathrm{ha}$ of carps (mainly silver carp Hypophthalmichthys molitrix and bighead carp Hypophthalmichthys nobilis), and fish are not fed with commercial feed but harvested annually; (2) group B $(n=4)$ or rural commercial fishing group (average area $=2005.0$ ha, average depth $=3.0 \mathrm{~m}$ ) is lakes surrounded by scattered farmlands and villages. These lakes were stocked with the above carps at around $600 \mathrm{~kg} / \mathrm{ha}$, and fish are harvested annually to provide aquatic products; (3) group C $(n=4)$ or urban park group (average area $=7.0$ ha, average depth $=1.8 \mathrm{~m}$ ) is extremely small ponds, located in the central urban area, surrounded by residential, commercial, and public facilities. Several park ponds were planted with Nelumbo nucifera, Myriophyllum spicatum, Ceratophyllum demersum, and other aquatic plants to improve water quality. These ponds are mainly used for sightseeing by local citizens. (4) Group $\mathrm{D}(n=4)$ or urban recreational fishing group (average area $=67.8 \mathrm{ha}$, average depth $=1.9 \mathrm{~m}$ ) is small lakes, located in the central urban area, surrounded by urban 


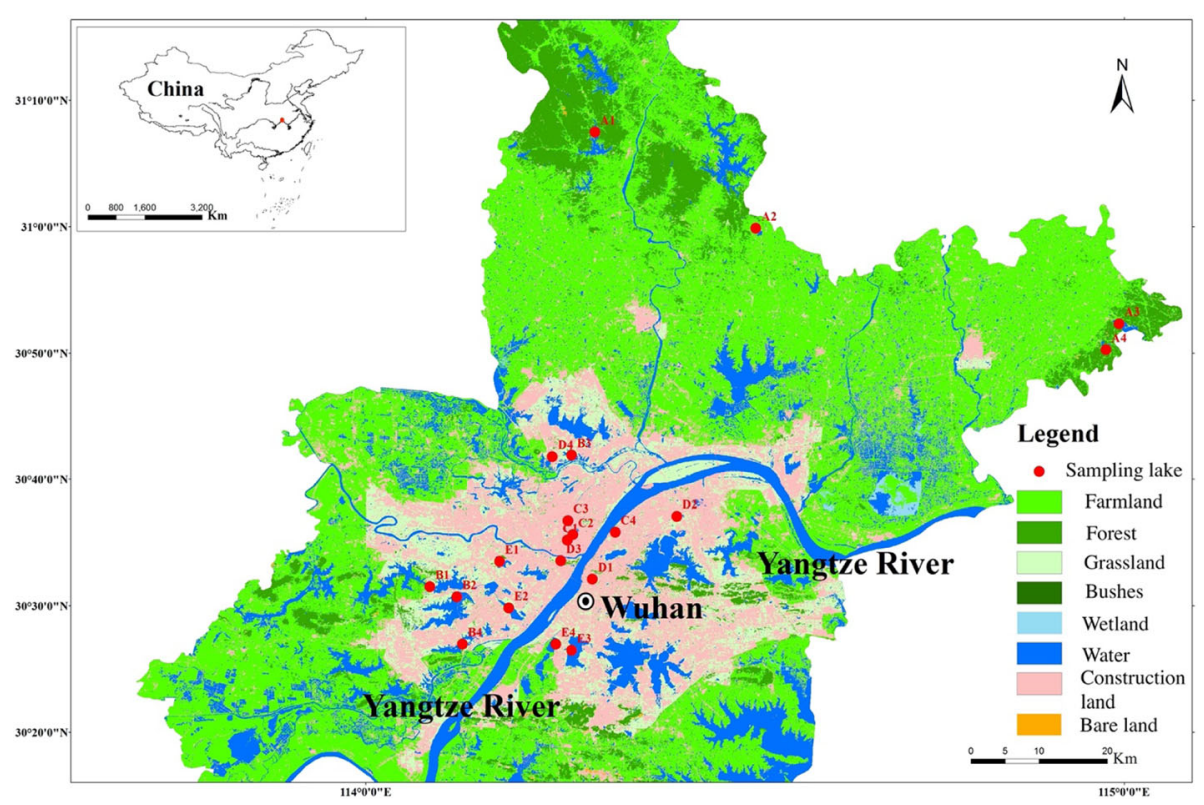

Fig. 1 Location of studied lakes along a rural to urban gradient in central China and the land use information of Wuhan city

Table 1 Basic information of sampling lakes along a rural to urban gradient in central China

\begin{tabular}{|c|c|c|c|c|c|c|c|c|}
\hline Group & Number & Lake name & Location & $\begin{array}{l}\text { Area } \\
\text { (ha) }\end{array}$ & $\begin{array}{l}\text { Altitude } \\
\text { (m) }\end{array}$ & $\begin{array}{l}\text { Water depth } \\
\text { (m) }\end{array}$ & $\begin{array}{l}\text { Air temperature } \\
\left({ }^{\circ} \mathrm{C}\right)\end{array}$ & $\begin{array}{l}\text { Water temperature } \\
\left({ }^{\circ} \mathrm{C}\right)\end{array}$ \\
\hline \multirow[t]{4}{*}{$\bar{A}$} & 1 & Yuanjisi & Rural & 556 & 39 & 12.3 & 32.2 & 28.6 \\
\hline & 2 & Wujiasi & Rural & 80 & 85 & 5.8 & 29.4 & 28.0 \\
\hline & 3 & Daoguanhe & Rural & 346 & 62 & 18.7 & 28.5 & 29.2 \\
\hline & 4 & Shaotanhe & Rural & 68 & 62 & 13.8 & 32.4 & 30.1 \\
\hline \multirow[t]{4}{*}{ B } & 1 & Zhiyinhu & Rural & 3000 & 10 & 2.6 & 33.2 & 28.6 \\
\hline & 2 & Houguanhu & Rural & 3186 & 11 & 2.8 & 34.5 & 29.0 \\
\hline & 3 & Panlonghu & Rural & 1467 & 53 & 4.3 & 31.5 & 30.2 \\
\hline & 4 & Zhushanhu & Rural & 367 & 14 & 2.3 & 34.1 & 29.6 \\
\hline \multirow[t]{4}{*}{$C$} & 1 & Zhongshan park & Urban & 6 & 20 & 1.3 & 29.4 & 25.7 \\
\hline & 2 & Xiaonanhu park & Urban & 4 & 20 & 1.7 & 31.4 & 28.8 \\
\hline & 3 & Lingjiaohu park & Urban & 9 & 29 & 2.2 & 34.0 & 33.0 \\
\hline & 4 & Simeitang park & Urban & 9 & 24 & 1.8 & 34.8 & 31.0 \\
\hline \multirow[t]{4}{*}{ D } & 1 & Ziyanghu & Urban & 20 & 24 & 1.8 & 33.9 & 31.3 \\
\hline & 2 & Yangchunhu & Urban & 58 & 16 & 1.3 & 25.9 & 24.9 \\
\hline & 3 & Yuehu & Urban & 60 & -4 & 1.7 & 34.0 & 30.9 \\
\hline & 4 & Tangrenhai & Urban & 133 & 20 & 2.6 & 29.0 & 28.7 \\
\hline \multirow[t]{4}{*}{ E } & 1 & Longyanghu & Urban & 1000 & 67 & 2.0 & 34.0 & 32.2 \\
\hline & 2 & Nantaizihu & Urban & 659 & 13 & 1.1 & 31.3 & 29.3 \\
\hline & 3 & Huangjiahu & Urban & 851 & 12 & 2.0 & 25.3 & 26.7 \\
\hline & 4 & Qinglinghu & Urban & 600 & 17 & 1.7 & 24.7 & 27.2 \\
\hline
\end{tabular}


roads and residential and commercial facilities. Some of these lakes were planted with ornamental aquatic plants such as Trapa bispinosa and Nelumbo nucifera. These lakes are mainly used for sightseeing and recreational fishing; (5) group E $(n=4)$ or urban commercial fishing group (average area $=777.5 \mathrm{ha}$, average depth $=1.7 \mathrm{~m}$ ) is mainly large lakes in the central urban area, and surrounded by many residential facilities. These lakes were stocked with the above carps at around $800 \mathrm{~kg} / \mathrm{ha}$, fed with commercial feed, and fish harvested annually to provide aquatic products. All lakes in this group had black mucky clay sediments.

\section{Sample collection and analysis}

Field sampling was conducted in the summer of 2015. We sampled 3 sites per lake for lakes with surface area $\leq$ 5 ha, and 4-6 sites per lake for lakes with surface area > 5 ha (MEP 2002; Xia et al. 2018). A 5-L plexiglass sampler was used to collect water samples at $0.5 \mathrm{~m}$ below the water surface (Xia et al. 2018). A cylindrical sediment sampler (inner diameter $=48.96 \mathrm{~mm}$ ) was used to collect the 5-cm surface sediment samples (Xia et al. 2018). Pretreatment of water and sediment samples followed standard methods (APHA 2005; Xia et al. 2018).

In the laboratory, we analyzed 11 heavy metals (based on urban activities in Wuhan and literature review) including cobalt $(\mathrm{Co})$, cadmium $(\mathrm{Cd})$, lead $(\mathrm{Pb})$, chromium $(\mathrm{Cr})$, arsenic $(\mathrm{As})$, nickel $(\mathrm{Ni})$, copper $(\mathrm{Cu})$, zinc $(\mathrm{Zn})$, magnesium $(\mathrm{Mn})$, iron $(\mathrm{Fe})$, and aluminum $(\mathrm{Al})$ by an inductively coupled plasma optical emission spectrometer (ICP-OES, PerkinElmer Inc., USA) and an inductively coupled plasma-mass spectrometer (ICP-MS, PerkinElmer Inc., USA), respectively (Xia et al. 2018). The detection limits and quality control measures were presented in our previous studies (Xia et al. 2018; Guo et al. 2020).

\section{Potential ecological risk index}

The level of heavy metal concentration in sediment was evaluated based on the potential ecological risk index (RI), which was proposed by Hakanson and had many applications (Hakanson 1980; Zhang and Shao 2013; Bi et al. 2018; Xia et al. 2018). We followed this method and calculated sediment RIs among the different lake groups (Xia et al. 2018).

\section{Enrichment factor}

Enrichment factor (EF) is an important geochemical index used for evaluating the source of heavy metals in sediments and is based on the assumption that under the natural sedimentation conditions, there is a linear relationship between a reference metal and other metals (Taylor 1964; Zhang et al. 1996; Chabukdhara and Nema
2012). The EF was computed using the relationship below:

$$
E F=\left(\frac{M}{M_{r}}\right) \text { sample } /\left(\frac{M}{M_{r}}\right) \text { background }
$$

where $\left(\frac{M}{M_{r}}\right)_{\text {sample }}$ is the metal to the reference metal ratio in the samples, $\left(\frac{M}{M_{r}}\right)_{\text {background }}$ is the geochemical background value of metal to the reference metal ratio. In most studies, $\mathrm{Al}, \mathrm{Fe}$, and $\mathrm{Sc}$ were often used as reference metals (Bhuiyan et al. 2010; Chabukdhara and Nema 2012; Dou et al. 2013). In this study, we used $\mathrm{Al}$ as the reference metal because of the following reasons: (1) $\mathrm{Al}$ is a conservative metal and its natural concentration tends to be uniform and (2) free from anthropogenic contribution (Zhang et al. 2006; Chabukdhara and Nema 2012). The background values of heavy metals in sediments in lakes of Hubei province were used to calculate the EF (Qiao et al. 2005; Tang et al. 2009). The EF values less than 1 suggest that heavy metals may be entirely from natural weathering processes, whereas EF $>1$ indicates that the heavy metal is of anthropogenic origin, EFs greater than 10 are considered to be non-crusted sources (Zsefer et al. 1996; Bhuiyan et al. 2010).

\section{Statistical analysis}

In this study, SPSS 20.0 was used for data analysis. First, we conducted descriptive analysis (e.g., means, standard deviations) for the 11 heavy metal elements from each sampling station, then the raw data were $\log _{10}$ transformed to meet the requirements of later parametric analysis. One-way ANOVA was used to compare the differences of heavy metal concentrations among the five lake groups in water and sediment. If there was a significant difference among the groups, then LSD multiple comparisons were conducted to identify the group difference. The significant difference was determined when $P<0.05$ for all analyses.

\section{Results}

Differences of heavy metals in water from rural to urban lakes

Concentrations of $\mathrm{Cd}, \mathrm{Co}, \mathrm{Pb}$, and $\mathrm{Cr}$ in suburban reservoir group (A) were significantly lower than those in other groups (Table 2, Fig. 2a-d; df $=4, F=6.12, P<$ $0.05 ; \mathrm{df}=4, F=8.90, P<0.05 ; \mathrm{df}=4, F=5.32, P<0.05$; $\mathrm{df}=4, F=4.29, P<0.05$, respectively). Co in urban park group (C) was significantly lower than that in urban commercial fishing group (E) (Table 2, Fig. 2b; $P<0.05$, $\mathrm{df}=4, F=8.90)$. Similar to $\mathrm{Cd}, \mathrm{Co}, \mathrm{Pb}$, and $\mathrm{Cr}$, concentrations of As and $\mathrm{Ni}$ in group A were significantly lower than those in other four groups (Table 2, Fig. 2e, f; $\mathrm{df}=$ $4, F=7.12, P<0.05 ; \mathrm{df}=4, F=16.45, P<0.05$, respectively). $\mathrm{Zn}$ in group A was significantly lower than that in 
Table 2 Descriptive statistical analysis of 11 heavy metals in water samples of lakes along a rural to urban gradient in central China (Mean \pm SD)

\begin{tabular}{|c|c|c|c|c|c|c|c|c|}
\hline \multirow{2}{*}{$\begin{array}{l}\text { Heavy } \\
\text { metals }\end{array}$} & \multicolumn{5}{|c|}{ Concentrations of heavy metals in different groups } & \multirow[t]{2}{*}{ df } & \multirow[t]{2}{*}{ F } & \multirow[t]{2}{*}{$P$} \\
\hline & $\mathrm{A}$ & B & C & $\mathrm{D}$ & $\mathrm{E}$ & & & \\
\hline $\mathrm{Cd}(\mu \mathrm{g} / \mathrm{L})$ & $0.05 \pm 0.01 a$ & $0.09 \pm 0.02 b$ & $0.15 \pm 0.04 b$ & $0.21 \pm 0.07 b$ & $0.15 \pm 0.02 b$ & 4 & 6.120 & $0.004^{* *}$ \\
\hline Co $(\mu \mathrm{g} / \mathrm{L})$ & $0.37 \pm 0.09 a$ & $1.51 \pm 0.74 b c$ & $1.16 \pm 0.59 b$ & $2.84 \pm 1.58 \mathrm{bc}$ & $3.30 \pm 1.36 c$ & 4 & 8.906 & $0.001^{* *}$ \\
\hline $\mathrm{Pb}(\mu \mathrm{g} / \mathrm{L})$ & $1.42 \pm 0.62 \mathrm{a}$ & $5.74 \pm 2.34 b$ & $5.13 \pm 2.10 b$ & $7.74 \pm 4.52 b$ & $10.04 \pm 8.44 b$ & 4 & 5.329 & $0.007^{* *}$ \\
\hline $\mathrm{Cr}(\mu \mathrm{g} / \mathrm{L})$ & $3.10 \pm 0.38 a$ & $9.93 \pm 2.36 b$ & $8.56 \pm 5.46 b$ & $11.40 \pm 5.69 b$ & $10.28 \pm 5.82 b$ & 4 & 4.290 & $0.016^{* *}$ \\
\hline As $(\mu \mathrm{g} / \mathrm{L})$ & $3.12 \pm 0.53 a$ & $18.52 \pm 12.64 b$ & $20.73 \pm 12.34 b$ & $15.16 \pm 5.07 b$ & $45.19 \pm 38.37 b$ & 4 & 7.126 & $0.002^{* *}$ \\
\hline $\mathrm{Ni}(\mu \mathrm{g} / \mathrm{L})$ & $5.30 \pm 0.61 a$ & $12.33 \pm 2.18 b$ & $11.48 \pm 2.70 \mathrm{~b}$ & $16.99 \pm 4.02 \mathrm{bc}$ & $18.22 \pm 3.23 c$ & 4 & 16.456 & $0.000^{* *}$ \\
\hline $\mathrm{Cu}(\mu \mathrm{g} / \mathrm{L})$ & $6.64 \pm 1.51$ & $11.97 \pm 5.06$ & $15.42 \pm 13.25$ & $15.82 \pm 5.93$ & $20.69 \pm 15.67$ & 4 & 1.277 & 0.322 \\
\hline Zn ( $\mu \mathrm{g} / \mathrm{L})$ & $10.35 \pm 1.16 a$ & $18.68 \pm 5.51 \mathrm{ab}$ & $22.25 \pm 8.75 b$ & $28.13 \pm 8.27 b$ & $25.46 \pm 10.75 b$ & 4 & 3.930 & $0.022^{*}$ \\
\hline $\mathrm{Mn}(\mu \mathrm{g} / \mathrm{L})$ & $43.46 \pm 13.45 a$ & $200.65 \pm 91.95 b$ & $150.75 \pm 68.54 b$ & $391.61 \pm 164.47 \mathrm{bc}$ & $656.24 \pm 139.43 c$ & 4 & 18.995 & $0.000^{* *}$ \\
\hline $\mathrm{Fe}(\mathrm{mg} / \mathrm{L})$ & $0.36 \pm 0.05 a$ & $2.28 \pm 1.49 b$ & $2.02 \pm 1.43 b$ & $5.19 \pm 4.15 b$ & $4.59 \pm 3.20 b$ & 4 & 5.599 & $0.006^{* *}$ \\
\hline $\mathrm{Al}(\mathrm{mg} / \mathrm{L})$ & $0.36 \pm 0.02 \mathrm{a}$ & $3.17 \pm 2.28 b$ & $2.46 \pm 1.29 b$ & $6.75 \pm 5.22 b$ & $5.59 \pm 4.06 b$ & 4 & 6.120 & $0.004^{* *}$ \\
\hline
\end{tabular}

* denotes significant difference $P<0.05 ;$ ** denotes significant difference $P<0.01$

groups $\mathrm{C}, \mathrm{D}$, and $\mathrm{E}$ (Table 2, Fig. 2h; $P<0.05$, $\mathrm{df}=4, F$ $=3.93)$. Concentration of $\mathrm{Ni}$ in groups $\mathrm{B}$ and $\mathrm{C}$ was significantly lower than those in group E (Table 2, Fig. 2f; $P$ $<0.05, \mathrm{df}=4, F=16.45)$. There were no significant differences detected in $\mathrm{Cu}$ among five groups (Table 2, Fig. $2 \mathrm{~g}$ ). Concentrations of $\mathrm{Mn}, \mathrm{Fe}$, and $\mathrm{Al}$ in group $\mathrm{A}$ were significantly lower than those in other groups (Table 2, Fig. 2i-k; df $=4, F=18.99, P<0.05 ; \mathrm{df}=4, F=5.59, P$ $<0.05 ; \mathrm{df}=4, F=6.12, P<0.05$, respectively). $\mathrm{Mn}$ in groups $\mathrm{B}$ and $\mathrm{C}$ were significantly lower than that in group E (Table 2, Fig. 2i; $P<0.05$, df $=4, F=18.99$ ).
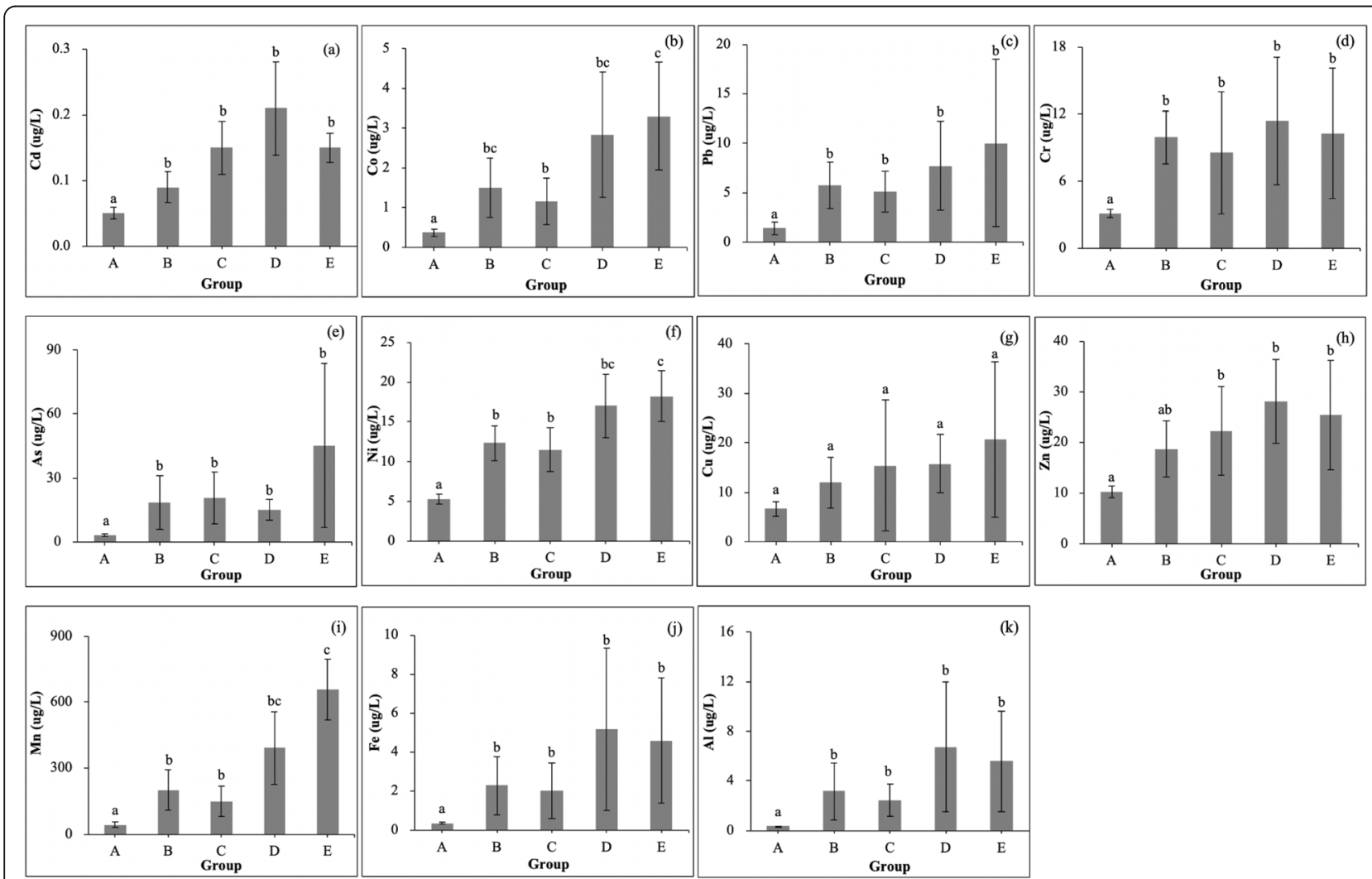

Fig. 2 Concentrations (mean $\pm \mathrm{SD}$ ) of a $\mathrm{Cd}, \mathbf{b} \mathrm{Co}, \mathbf{c} \mathrm{Pb}, \mathbf{d} \mathrm{Cr}$, e As, f Ni, $\mathbf{g ~ C u}, \mathbf{h} \mathrm{Zn}, \mathbf{i} \mathrm{Mn}$, j Fe, and $\mathbf{k} \mathrm{Al}$ in water samples of lakes along a rural to urban gradient in central China. Note: different letters above bars indicate significant group difference $(P<0.05)$ 
Table 3 Water quality standards for both surface water and fisheries by Ministry of Environmental Protection, People's Republic of China (MEP 1990, 2002)

\begin{tabular}{|c|c|c|c|c|c|c|c|c|c|}
\hline Standards & Classification $(\leq)$ & $\mathrm{Cu}(\mu \mathrm{g} / \mathrm{L})$ & $\mathrm{Zn}(\mu \mathrm{g} / \mathrm{L})$ & As $(\mu \mathrm{g} / \mathrm{L})$ & $\mathrm{Cd}(\mu \mathrm{g} / \mathrm{L})$ & $\mathrm{Cr}(\mu \mathrm{g} / \mathrm{L})$ & $\mathrm{Pb}(\mu \mathrm{g} / \mathrm{L})$ & $\mathrm{Cd}(\mu \mathrm{g} / \mathrm{L})$ & $\mathrm{Ni}(\mu \mathrm{g} / \mathrm{L})$ \\
\hline \multirow[t]{5}{*}{ Surface water quality } & 1 & 10 & 50 & 50 & 1 & 10 & 10 & -- & -- \\
\hline & $\|$ & 1000 & 1000 & 50 & 5 & 50 & 10 & -- & -- \\
\hline & III & 1000 & 1000 & 50 & 5 & 50 & 50 & -- & -- \\
\hline & IV & 1000 & 2000 & 100 & 5 & 50 & 50 & -- & -- \\
\hline & V & 1000 & 2000 & 100 & 10 & 100 & 100 & -- & -- \\
\hline Fishery water quality & Limit value & 100 & 10 & 50 & 0.5 & 50 & 5 & 0.5 & 100 \\
\hline
\end{tabular}

According to the surface water quality standards by China Ministry of Environmental Protection (MEP) (2002) and water quality standards for fisheries by MEP (1990) (Table 3), suburban reservoirs in group A belong to class I mainly applicable to the water sources and national nature reserve. Lakes in the other four groups belong to class II mainly applicable to the first-grade protection zone of surface water sources, habitats of rare aquatic organisms, fish and shrimp production grounds, and the feeding ground of juveniles and young fishes (Table 3). Only the concentrations of $\mathrm{Zn}$ and $\mathrm{Pb}$ in groups $\mathrm{B}$ and $\mathrm{E}$ exceeded the water quality standard for fisheries (Table 3).

\section{Differences of heavy metals in sediments from rural to urban lakes}

Concentration of As in group A was significantly lower than that in other groups (Table 4, Fig. 3b; $P<0.05$, df = $4, F=6.65)$. There were no significant differences detected in $\mathrm{Cd}, \mathrm{Co}$, and $\mathrm{Ni}$ among five groups (Table 4 , Fig. 3a, c, d). There were no significant differences detected in any of the seven metals among the five groups (Table 4, Fig. 3e-k).
The results showed that EF values of all selected heavy metals in sediment samples of lakes along a rural to urban gradient in Wuhan city were higher than 1.0 , and sediments in lakes showed a wide range of heavy metal enrichment (Table 5). The EF values of these heavy metals in different groups showed the following: group $\mathrm{A}, \mathrm{Cd}>$ $\mathrm{Cu}>\mathrm{Cr}>\mathrm{Zn}>\mathrm{Co}>\mathrm{Mn}>\mathrm{Pb}>\mathrm{Fe}>\mathrm{Ni}>$ As; group $\mathrm{B}$, $\mathrm{Cd}>\mathrm{Cu}>\mathrm{Zn}>\mathrm{Pb}>\mathrm{Cr}>\mathrm{Ni}>\mathrm{Fe}>\mathrm{Co}>\mathrm{Mn}>$ As; group $\mathrm{C}, \mathrm{Cd}>\mathrm{Cu}>\mathrm{Zn}>\mathrm{Ni}>\mathrm{Cr}>\mathrm{Co}>\mathrm{Fe}>\mathrm{Pb}>\mathrm{Mn}>\mathrm{As}$; group $\mathrm{D}, \mathrm{Cd}>\mathrm{Cu}>\mathrm{Zn}>\mathrm{Ni}>\mathrm{Cr}>\mathrm{Co}>\mathrm{Pb}>\mathrm{Fe}>\mathrm{Mn}>$ As; and group $\mathrm{E}, \mathrm{Cd}>\mathrm{Ni}>\mathrm{Zn}>\mathrm{Cu}>\mathrm{Cr}>\mathrm{Co}>\mathrm{Fe}>\mathrm{Pb}$ $>\mathrm{As}>\mathrm{Mn}$ (Table 5). The mean values of $\mathrm{EF}$ in group $\mathrm{A}$ showed moderately severe enrichment for $\mathrm{Cd}$ and $\mathrm{Cu}$, moderate enrichment for $\mathrm{Cr}, \mathrm{Zn}, \mathrm{Co}, \mathrm{Mn}, \mathrm{Pb}$, and $\mathrm{Fe}$, and minor enrichment for $\mathrm{Ni}$ and $\mathrm{As}$; $\mathrm{EF}$ values in group $\mathrm{B}$ showed moderate enrichment for $\mathrm{Cd}, \mathrm{Cu}$, and $\mathrm{Zn}$ and minor enrichment for $\mathrm{Pb}, \mathrm{Cr}, \mathrm{Ni}, \mathrm{Fe}, \mathrm{Co}, \mathrm{Mn}$, and $\mathrm{As}$; $\mathrm{EF}$ values in group $\mathrm{C}$ showed moderately severe enrichment for $\mathrm{Cd}$, moderate enrichment for $\mathrm{Cu}, \mathrm{Zn}$, and $\mathrm{Ni}$ and minor enrichment for $\mathrm{Cr}, \mathrm{Co}, \mathrm{Fe}, \mathrm{Pb}, \mathrm{Mn}$, and $\mathrm{As}$; $\mathrm{EF}$ values in group $\mathrm{D}$ showed moderately severe enrichment for $\mathrm{Cd}$, moderate enrichment for $\mathrm{Cu}, \mathrm{Zn}$, and $\mathrm{Ni}$, and minor enrichment for $\mathrm{Cr}, \mathrm{Co}, \mathrm{Pb}, \mathrm{Fe}, \mathrm{Mn}$, and $\mathrm{As}$; $\mathrm{EF}$ values in group $\mathrm{E}$ showed moderately severe enrichment

Table 4 Descriptive statistical analysis of 11 heavy metals in sediment samples of lakes along a rural to urban gradient in central China (Mean \pm SD)

\begin{tabular}{|c|c|c|c|c|c|c|c|c|}
\hline \multirow{2}{*}{$\begin{array}{l}\text { Heavy } \\
\text { metals }\end{array}$} & \multicolumn{5}{|c|}{ Concentrations of heavy metals in different groups } & \multirow[t]{2}{*}{ df } & \multirow[t]{2}{*}{$F$} & \multirow[t]{2}{*}{$P$} \\
\hline & $A$ & B & C & D & $E$ & & & \\
\hline $\mathrm{Cd}(\mathrm{mg} / \mathrm{kg})$ & $0.50 \pm 0.16$ & $0.32 \pm 0.06$ & $0.61 \pm 0.16$ & $0.76 \pm 0.52$ & $0.45 \pm 0.11$ & 4 & 1.904 & 0.162 \\
\hline As $(\mathrm{mg} / \mathrm{kg})$ & $6.53 \pm 1.89 a$ & $10.04 \pm 1.05 b$ & $10.69 \pm 0.85 b$ & $10.66 \pm 0.84 b$ & $11.15 \pm 1.49 b$ & 4 & 6.651 & $0.003^{* *}$ \\
\hline $\mathrm{Co}(\mathrm{mg} / \mathrm{kg})$ & $19.81 \pm 7.54$ & $15.93 \pm 1.40$ & $14.12 \pm 1.37$ & $16.10 \pm 0.95$ & $16.63 \pm 1.09$ & 4 & 1.044 & 0.417 \\
\hline $\mathrm{Ni}(\mathrm{mg} / \mathrm{kg})$ & $32.10 \pm 9.24$ & $43.67 \pm 4.25$ & $40.47 \pm 3.30$ & $45.38 \pm 3.29$ & $44.61 \pm 3.50$ & 4 & 2.867 & 0.06 \\
\hline $\mathrm{Pb}(\mathrm{mg} / \mathrm{kg})$ & $32.59 \pm 6.55$ & $29.51 \pm 2.15$ & $62.87 \pm 27.83$ & $35.38 \pm 4.16$ & $39.06 \pm 11.88$ & 4 & 4.044 & 0.02 \\
\hline $\mathrm{Cu}(\mathrm{mg} / \mathrm{kg})$ & $105.45 \pm 113.98$ & $37.37 \pm 5.47$ & $93.72 \pm 74.94$ & $46.60 \pm 8.85$ & $62.65 \pm 35.21$ & 4 & 0.754 & 0.571 \\
\hline $\mathrm{Zn}(\mathrm{mg} / \mathrm{kg})$ & $105.75 \pm 43.16$ & $95.97 \pm 13.15$ & $166.71 \pm 4.71$ & $115.36 \pm 20.40$ & $134.41 \pm 37.27$ & 4 & 2.947 & 0.056 \\
\hline $\mathrm{Cr}(\mathrm{mg} / \mathrm{kg})$ & $111.35 \pm 43.93$ & $95.50 \pm 4.89$ & $111.29 \pm 36.18$ & $94.42 \pm 6.45$ & $99.78 \pm 8.47$ & 4 & 0.219 & 0.923 \\
\hline$M n(g / k g)$ & $0.97 \pm 0.64$ & $0.42 \pm 0.14$ & $0.59 \pm 0.10$ & $0.63 \pm 0.20$ & $0.71 \pm 0.16$ & 4 & 1.637 & 0.217 \\
\hline $\mathrm{Fe}(\mathrm{g} / \mathrm{kg})$ & $37.57 \pm 12.66$ & $38.64 \pm 3.11$ & $38.26 \pm 3.01$ & $39.75 \pm 3.60$ & $39.90 \pm 3.08$ & 4 & 0.232 & 0.916 \\
\hline $\mathrm{Al}(\mathrm{g} / \mathrm{kg})$ & $25.77 \pm 15.58$ & $23.60 \pm 9.40$ & $45.50 \pm 3.29$ & $34.45 \pm 15.30$ & $33.76 \pm 16.50$ & 4 & 1.517 & 0.247 \\
\hline
\end{tabular}

* denotes significant difference $P<0.05$; ${ }^{* *}$ denotes significant difference $P<0.01$ 

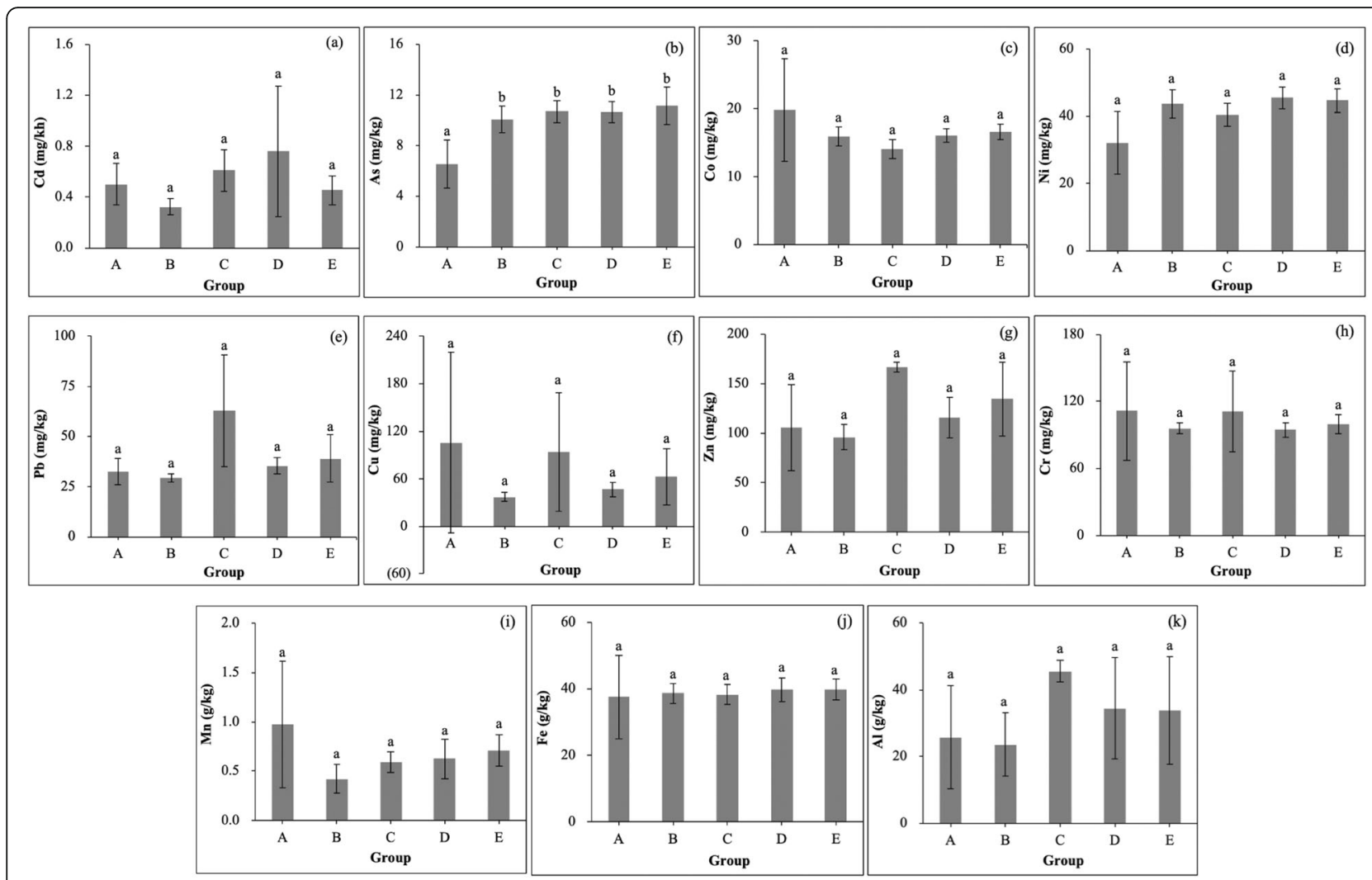

Fig. 3 Concentrations (mean $\pm \mathrm{SD}$ ) of a Cd, b As, c Co, $\mathbf{d ~ N i}$, e Pb, $\mathbf{f} \mathrm{Cu}, \mathbf{g} \mathrm{Zn}, \mathbf{h} \mathrm{Cr}, \mathbf{i} \mathrm{Mn}, \mathbf{j}$ Fe, and $\mathbf{k} \mathrm{Al}$ in sediment samples of lakes along a rural to urban gradient in central China. Note: different letters above bars indicate significant group difference $(P<0.05)$

for $\mathrm{Cd}$, moderate enrichment for $\mathrm{Ni}, \mathrm{Zn}, \mathrm{Cu}, \mathrm{Cr}, \mathrm{Co}, \mathrm{Fe}$, and $\mathrm{Pb}$, minor enrichment for As and $\mathrm{Mn}$ (Table 5).

The potential ecological risk factor $\left(E_{r}^{i}\right)$ (Table 6) of $\mathrm{Cu}, \mathrm{Pb}, \mathrm{Cd}, \mathrm{Zn}, \mathrm{Cr}$, and As in sediment had the following rankings based on lake type: groups $\mathrm{A}$ and $\mathrm{C}-\mathrm{As}>$ $\mathrm{Cd}>\mathrm{Cu}>\mathrm{Cr}>\mathrm{Pb}>\mathrm{Zn}$; groups $\mathrm{B}, \mathrm{D}$, and $\mathrm{E}-\mathrm{As}>\mathrm{Cd}$ $>\mathrm{Cr}>\mathrm{Cu}>\mathrm{Pb}>\mathrm{Zn}$. The maximum $\mathrm{RI}$ value was 75.61 in group $\mathrm{C}$, which is still within the low risk category (Table 6).

\section{Discussion}

Differences of heavy metals in water from rural to urban lakes

Most of the studied heavy metals in the urban lakes (groups $\mathrm{C}, \mathrm{D}$, and E) were significantly higher than those in the rural reservoirs (group A), and concentrations of $\mathrm{Cd}, \mathrm{Co}, \mathrm{Pb}, \mathrm{Ni}, \mathrm{Cu}, \mathrm{Zn}, \mathrm{Mn}, \mathrm{Fe}$, and $\mathrm{Al}$ in groups $\mathrm{D}$ and $\mathrm{E}$ were higher than those in the rural commercial fishing group (group B), which indicated that urban processes have a clear impact on heavy metals in lake water.

Table 5 Enrichment factor (EF) of heavy metals in sediments of lakes along a rural to urban gradient in central China and grade standards for EF (Birth 2003)

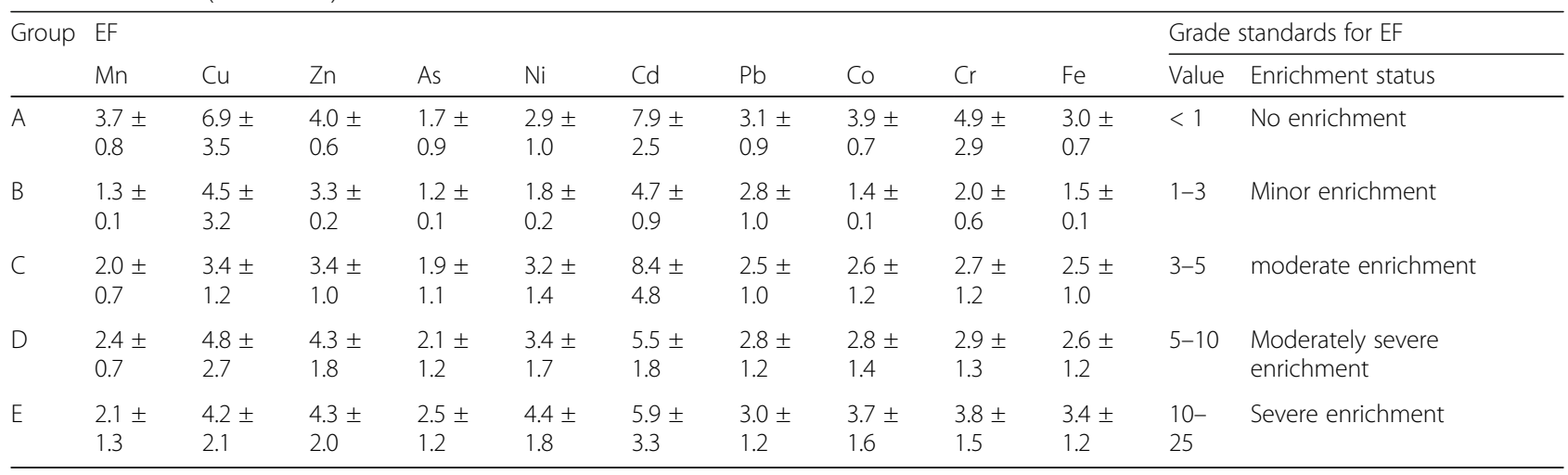


Table 6 Potential ecological risk index (RI) of metals in sediments of lakes along a rural to urban gradient in central China

\begin{tabular}{|c|c|c|c|c|c|c|c|c|}
\hline \multirow[t]{2}{*}{ Group } & \multicolumn{6}{|l|}{$E_{r}^{i \mathrm{a}}$} & \multirow[t]{2}{*}{$\mathrm{Rl}^{\mathrm{b}}$} & \multirow[t]{2}{*}{ RI ranges and categories } \\
\hline & $\overline{\mathrm{Cu}}$ & $\mathrm{Pb}$ & $\mathrm{Cd}$ & $\mathrm{Zn}$ & $\mathrm{Cr}$ & As & & \\
\hline A & 10.55 & 2.33 & 15 & 0.6 & 2.47 & 33.35 & 64.3 & $\mathrm{RI}<112.5$ low \\
\hline B & 3.74 & 2.11 & 9.72 & 0.55 & 6.7 & 41.7 & 64.52 & $112.5 \leq \mathrm{RI}<225$ moderate \\
\hline C & 9.37 & 4.49 & 18.38 & 0.95 & 7.12 & 35.3 & 75.61 & $225 \leq \mathrm{RI}<450$ considerable \\
\hline D & 4.66 & 2.53 & 22.77 & 0.66 & 7.11 & 34.85 & 72.58 & $\mathrm{Rl} \geq 450$ high \\
\hline E & 6.27 & 2.79 & 13.58 & 0.77 & 7.43 & 26.16 & 57 & \\
\hline
\end{tabular}

Note: ${ }^{\mathrm{a}} E_{r}^{i}$ is the potential ecological risk factor for individual heavy metals; ${ }^{\mathrm{b}} \mathrm{RI}$ represents the sensitivity of the biological community to toxic substance and illustrates the potential ecological risk caused by the overall contamination

Rural reservoirs in group A serve as backup drinking and irrigation water sources in the suburb of Wuhan. These reservoirs are located far away from the urban area and are surrounded by hills and farmlands. The frequency and intensity of human activities surrounding these reservoirs were significantly lower than lakes in the other groups. The possible sources of heavy metals to these reservoirs are mainly natural weathering, rain erosion of bare rocks, and atmospheric deposition (Wang et al. 2014; Zhang et al. 2015; Xia et al. 2018). The results are consistent with the previous studies (Islam et al. 2015; Yang et al. 2017) that the concentrations of heavy metals in urban ponds were generally higher than those in the suburban nature ponds, and the urban land use and anthropogenic factors played an important role in heavy metal pollutions of urban lakes and rivers.

Lakes in group B were in the rural area of Wuhan and less affected by human activities related to aquaculture. Previous studies indicated that chemicals such as copper sulfate are often used as algaecide, which could be the main source of heavy metals in water (Farmaki et al. 2014; Xia et al. 2018; Zhang et al. 2019). Lakes in groups $\mathrm{C}, \mathrm{D}$, and $\mathrm{E}$ were in the central urban area of Wuhan City, which were surrounded by paved roads, parking lots, and intensive residential and commercial facilities. Heavy metals in these lakes are more affected by urbanrelated activities. Compared to groups $\mathrm{C}$ and $\mathrm{D}$, it seems aquaculture activities in group $\mathrm{E}$ did not significantly change the heavy metals in these urban lakes.

Many studies showed that urbanization increased heavy metal concentrations in surface water (Chalmers et al. 2014; Zhang et al. 2015). Heavy metals are emitted into the environment through vehicle exhaust, waste disposal, fossil fuel combustion, and atmospheric deposition (Ferreira et al. 2016; Huber et al. 2016). Industries, such as coal, lead-zinc mining, steel manufacturing, and other activities have gradually increased in Wuhan. The discharge of industrial and municipal effluents as well as runoff from streets includes heavy metals such as $\mathrm{Pb}$, $\mathrm{Zn}$, and $\mathrm{Cu}$ (Kayhanian 2012; Huber et al. 2016). According to Maanan et al. (2014), $\mathrm{Ni}$ and $\mathrm{Cr}$ are the main pollutants originating from urban sewage.

\section{Differences of heavy metals in sediments from rural to urban lakes}

The EF values for all of the selected heavy metals were higher than 1.0 indicating that the heavy metals in sediments were enriched from man-made materials. There were no significant differences of studied heavy metals among the five groups except for As, which could potentially indicate that As in sediments was relatively more sensitive to urban processes than other elements. But EF values showed minor enrichment for As in all groups, which indicated that the overall influence of anthropogenic activities on As in sediments was limited. Human disturbance and non-point pollution may be the source of elevated As in other lake groups (Wang et al. 2019). Studies indicated that anthropogenic activities including mining, metal smelting, coal combustion, and burning of other fossil fuels can introduce excess As to lake, and As dissolved in the water column are readily deposited into sediments due to its high affinity for suspended particles (Zeng et al. 2014; Gao et al. 2017). Therefore, it was not surprising to observe high As concentrations in urban lake sediment (groups C, D, and E). Zhang et al. (2019) also showed that As in recent sediments was much more abundant than in earlier deposits indicating the increase in As pollution, likely derived from pesticide residues. This may be the reason for relatively high As concentration in rural commercial fishing lakes in group B as well, which were surrounded by farmlands.

The EF values showed that the sources of heavy metals in sediments were more likely to be anthropogenic. Although the reservoirs in group A received little direct human disturbances from surrounding watersheds, heavy metal inputs potentially from atmospheric deposition and surface runoff could be gradually increased after a long-term accumulation and enrichment (Ma et al. 2013; Goretti et al. 2016). Sediments in the five groups could have been affected by a variety of external activities for a long time. Heavy metals accumulate in the surface sediments through adsorption, complexation, precipitation, and organic flocculation, and integrate heavy metal load over longer time. This slow and lasting effect may be an important reason why the differences 
of heavy metals in sediments among groups were not as significant as that in water, and potentially makes sediments less sensitive to urbanization compared to water in the studied lakes.

The EF values showed moderately severe enrichment for $\mathrm{Cd}$ in sediments of most studied lakes, and RI index showed that $\mathrm{Cd}$ was the metal with highest concern as a risk factor, which indicated that $\mathrm{Cd}$ concentration in sediments of the studied lakes was seriously affected by anthropogenic activities. Previous studies have shown that the distribution of $\mathrm{Cd}$ was closely related to the extensive industrial and agricultural activities (Zhang and Shan, 2008; Bai et al., 2011; Li et al., 2014). The potential ecological risks of all the studied heavy metals in sediments were low in the five groups indicating that heavy metals were enriched in the sediments to a certain degree but did not reach the ecological risk level. Heavy metals accumulate in the surface sediments through a slow and complex process and could increase over time. Therefore, the urban wastes including gas, solids, and effluents need to be monitored periodically and extensively to meet the emission and discharge standards to control the level of heavy metal pollution in the region.

\section{Conclusions}

In lake water, concentrations of $\mathrm{Co}, \mathrm{Pb}, \mathrm{Cr}, \mathrm{As}, \mathrm{Ni}, \mathrm{Mn}$, $\mathrm{Fe}$, and $\mathrm{Al}$ were the lowest in the rural reservoir group, and most of the studied heavy metals in urban groups were higher than those in rural groups. These results indicated that urbanization risks increasing the concentrations of heavy metals in lake water. In sediments, concentration of As in rural group A was significantly lower than that in other groups, while concentrations of other metals had no significant differences among groups. The EF values of selected heavy metals showed there were different degrees of enrichments of heavy metals in sediments, and the sources of heavy metals in sediments were more likely from anthropogenic activities. Metals in sediments of all studied lakes were at low ecological risk levels. Current study suggested that lakes in urban area may need further attention in terms of heavy metal management. This research could be a reference for the heavy metal pollution prevention and sustainable urban ecosystem management in the central Yangtze River Basin of China and may also be applied to other aquatic ecosystems globally.

\footnotetext{
Abbreviations

Co: Cobalt; Cd: Cadmium; Pb: Lead; Cr: Chromium; As: Arsenic; Ni: Nickel;

Cu: Copper; Zn: Zinc; Mn: Magnesium; Fe: Iron; Al: Aluminum; ICP-

OES: Inductively coupled plasma optical emission spectrometer; ICP-

MS: Inductively coupled plasma-mass spectrometer
}

\section{Acknowledgements}

We thank many graduate and undergraduate students who helped with field sampling and laboratory analysis in this study.

\section{Authors' contributions}

All authors contributed to the study conception and design. Material preparation, data collection, and analysis were performed by Wentong Xia, Rui Wang, and Yushun Chen. The first draft of the manuscript was written by Wentong Xia, and all authors commented and revised on previous versions of the manuscript. All authors read and approved the final manuscript.

\section{Funding}

This work was supported by the National Key R\&D Program of China (2019YFD0901201), the Chinese Academy of Sciences (Hundred Talent Program Y62302, Institute Talent Program Y45Z04, and Key Strategic Program ZDRW-ZS-2017-3-2), and State Key Laboratory of Freshwater Ecology and Biotechnology (grants 2016FBZ10 and 2019FBZ02).

\section{Availability of data and materials}

All data will be available in the data center of Institute of Hydrobiology, Chinese Academy of Sciences (www.hib.ac.cn).

Ethics approval and consent to participate Not applicable.

\section{Consent for publication}

Not applicable.

\section{Competing interests}

The authors declare that they have no competing interest.

\section{Author details}

${ }^{1}$ State Key Laboratory of Freshwater Ecology and Biotechnology, Institute of Hydrobiology, Chinese Academy of Sciences, Wuhan 430072, China. ${ }^{2}$ University of Chinese Academy of Sciences, Beijing 100049, China. ${ }^{3}$ Key laboratory of Ecological Impacts of Hydraulic-Projects and Restoration of Aquatic Ecosystem of Ministry of Water Resources \& Institute of Hydroecology, Ministry of Water Resource and Chinese Academy of Sciences, Wuhan 430079, China. ${ }^{4}$ Department of Biology, University of Hartford, West Hartford, CT 06117, USA. ${ }^{5}$ Cornell Biological Field Station and Department of Natural Resources, Cornell University, 900 Shackelton Point Road, Bridgeport, NY 13030, USA. 'Water Environment Institute, Chinese Academy of Environmental Planning, Beijing 100012, China.

Received: 9 June 2020 Accepted: 10 August 2020

Published online: 15 September 2020

\section{References}

APHA (American Public Health Association) (2005) Standard methods for the examination of water and wastewater (2 $1^{\text {st }}$ edition). American Public Health Association, American Water Works Association, and Water Environment Federation.

Bai J, Xiao R, Cui B, Zhang K, Wang Q, Liu X, Gao H, Huang L (2011) Assessment of heavy metal pollution in wetland soils from the young and old reclaimed regions in the Pearl River estuary, South China. Environ Pollut 159:817-824

Bhuiyan MAH, Parvez L, Islam MA, Dampare SB, Suzuki S (2010) Heavy metal pollution of coal mine-affected agricultural soils in the northern part of Bangladesh. J Hazard Mater 173:384-392

Bhuiyan MAH, Suruvi NI, Dampare SB, Islam MA, Quraishi SB, Ganyaglo S, Suzuki S (2011) Investigation of the possible sources of heavy metal contamination in lagoon and canal water in the tannery industrial area in Dhaka, Bangladesh. Environ Monit Assess 175:633-649

Bi B, Liu X, Guo X, Lu S (2018) Occurrence and risk assessment of heavy metals in water, sediment, and fish from Dongting Lake, China. Environ Sci Pollut R 25: 34076-34090

Bing HJ, Zhou J, Wu Y, Wang X, Sun H, Li R (2016) Current state, sources, and potential risk of heavy metals in sediments of Three Gorges Reservoir, China. Environ Pollut 214:485-496

Birth G (2003) A scheme for assessing human impacts on coastal aquatic environments using sediments. In: Woodcoffe CD, Furness RA (eds) Coastal GIS. Wollongong University Papers in Center for Maritime Policy, Wollongong, NSW, Australia

Bissen M, Frimmel FH (2003) Arsenic - a review. Part l: occurrence, toxicity, speciation, mobility. Acta Hydrochim Hydrobiol 31:9-18 
Chabukdhara M, Nema AK (2012) Assessment of heavy metal contamination in Hindon River sediments: a chemometric and geochemical approach. Chemosphere 87:945-953

Chalmers AT, Krabbenhoft DP, Van Metre PC, Nilles MA (2014) Effects of urbanization on mercury deposition and accumulation in New England. Environ Pollut 192:104-112

Chen HZ, Shi TZ, Wu GF (2015) The dynamic analysis of lake landscape of Wuhan City in recent 40 years. J Lake Sci 27:745-754 (in Chinese)

Chowdhury S, Mazumder MAJ, Al-Attas O, Husain T (2016) Heavy metals in drinking water: occurrences, implications, and future needs in developing countries. Sci Total Environ 569-570:476-488

Dou Y, Li J, Zhao J, Hu B, Yang S (2013) Distribution, enrichment and source of heavy metals in surface sediments of the eastern Beibu Bay, South China Sea. Mar Pollut Bull 67:137-145

Farmaki EG, Thomaidis NS, Pasias IN, Baulard C, Papaharisis L, Efstathiou CE (2014) Environmental impact of intensive aquaculture: investigation on the accumulation of metals and nutrients in marine sediments of Greece. Sci Total Environ 485:554-562

Ferreira CSS, Walsh RPD, de Lourdes CM, Coelho COA, Ferreira AJD (2016) Dynamics of surface water quality driven by distinct urbanization patterns and storms in a Portuguese peri-urban catchment. J Soils Sediments 16: 2606-2621

Gao L, Wang Z, Shan J, Chen J, Tang C, Yi M (2017) Aquatic environmental changes and anthropogenic activities reflected by the sedimentary records of the Shima River, southern China. Environ Pollut 224:70-81

Garrett RG (2000) Natural sources of metals to the environment. Hum Ecol Risk Assess 6:465-470

Goretti E, Pallottini M, Ricciarini Ml, Selvaggi R, Cappelletti D (2016) Heavy metals bioaccumulation in selected tissues of red swamp crayfish: an easy tool for monitoring environmental contamination levels. Sci Total Environ 559:339346

Graves GA, Wan Y, Fike DL (2004) Water quality characteristics of storm water from major land uses in South Florida. J Am Water Resour As 40:1405-1419

Grigas D, Lehrter J, Cebrian J, Chen Y, Ehmen B, Woodrey M (2015) Effects of stormwater pipe size and rainfall on sediment and nutrients delivered to a coastal bayou. Water Environ Res 87:796-804

Guo C, Chen Y, Xia W, Qu X, Yuan H, Xie S, Lin LS (2020) Eutrophication and heavy metal pollution patterns in the water suppling lakes of China's southto-north water diversion project. Sci Total Environ 711:134543

Guo Y, Yang S (2016) Heavy metal enrichments in the Changjiang (Yangtze River) catchment and on the inner shelf of the East China Sea over the last 150 years. Sci Total Environ 543:105-115

Hakanson L (1980) An ecological risk index for aquatic pollution control: a sedimentological approach. Water Res 14:975-1001

Hao L, Sun L, Zhao Y, Lu J (2013) Sedimentary records of evolution of heavy metals in Songhua Lake, Northeast China. Clean-Soil Air Water 41:1010-1017

Huber M, Welker A, Helmreich B (2016) Critical review of heavy metal pollution of traffic area runoff: occurrence, influencing factors, and partitioning. Sci Total Environ 541:895-919

Islam MS, Ahmed MK, Raknuzzaman M, Mamun MHA, Islam MK (2015) Heavy metal pollution in surface water and sediment: a preliminary assessment of an urban river in a developing country. Ecol Indic 48:282-291

Kayhanian M (2012) Trend and concentrations of legacy lead (Pb) in highway runoff. Environ Pollut 160:169-177

Li HB, Yu S, Li GL et al (2012) Urbanization increased metal levels in lake surface sediment and catchment topsoil of waterscape parks. Sci Total Environ 432 202-209

Li HB, Yu S, Li GL et al (2013) Spatial distribution and historical records of mercury sedimentation in urban lakes under urbanization impacts. Sci Total Environ 445:117-125

Li J, Pu L, Zhu M, Liao Q, Wang H, Cai F (2014) Spatial pattern of heavy metal concentration in the soil of rapid urbanization area: a case of Ehu town, Wuxi city, eastern China. Environ Earth Sci 71:3355-3362

Ma Z, Chen K, Yuan Z, Bi J, Huang L (2013) Ecological risk assessment of heavy metals in surface sediments of six major Chinese freshwater lakes. J Environ Qual 42:341-350

Maanan M, Ruiz-Fernandez AC, Maanan M, Fattal P, Zourarah B, Sahabi M (2014) A long-term record of land use change impacts on sediments in Oualidia lagoon, Morocco. Int J Sediment Res 29:1-10
MEP (Ministry of Environmental Protection of China) (2002) GB/T 3838-2002, Surface water quality standards by Ministry of Environmental Protection, People's Republic of China

MEP (Ministry of Environmental Protection of China) (1990) GB/T 11607-89, Water quality standards for fisheries by Ministry of Environmental Protection, People's Republic of China.

Noli F, Tsamos P (2016) Concentration of heavy metals and trace elements in soils, water and vegetables and assessment of health risk in the vicinity of a lignite-fired power plant. Sci Total Environ 563:377-385

Priadi C, Ayrauk S, Pacini S, Bonte P (2011) Urbanization impact on metals mobility in riverine suspended sediment: role of metal oxides. Int J Environ Sci Te 8:1-18

Qiao SY, Jiang YY, Xiang W, Tang JH (2005) Distribution of heavy metals in sediments in lakes in Wuhan with assessment on their potential ecological risk. Resour Environ Yangtze River 14:353-357 (in Chinese)

Rattan RK, Datta SP, Chhonkar PK, Suribabu K, Singh AK (2005) Long-term impact of irrigation with sewage effluents on heavy metal content in soils, crops and groundwater - a case study. Agric Ecosyst Environ 109:310-322

Scheibye K, Weisser J, Borggaard OK et al (2014) Sediment baseline study of levels and sources of polycyclic aromatic hydrocarbons and heavy metals in Lake Nicaragua. Chemosphere 95:556-565

Song K, Adams CJ, Burgin AJ (2017) Relative importance of external and internal phosphorus loadings on affecting lake water quality in agricultural landscapes. Ecol Eng 108:482-488

Tang ZW, Cheng JL, Yue Y, Chen YM (2009) Accumulations and risks of heavy metals in the sediments from 8 typical lakes in Wuhan, China. J Lake Sci 12 $61-68$

Taylor SR (1964) Abundance of chemical elements in the continental crust: a new table. Geochim Cosmochim Acta 28:1273-1285

Valtanen M, Sillanpaa N, Setala H (2014) The effect of urbanization on runoff pollutant concentrations, loadings and their seasonal patterns under cold climate. Water Air Soil Poll 225:1-16

Wang L, Lyons J, Kanehl P, Bannerman R (2001) Impacts of urbanization on stream habitat and fish across multiple spatial scales. Environ Manag 28:255-266

Wang S, Wang W, Chen J, Zhao L, Zhang B, Jiang X (2019) Geochemical baseline establishment and pollution source determination of heavy metals in Lake sediments: a case study in Lihu lake, China. Sci Total Environ 657:978-986

Wang Z, Yao L, Liu G, Liu W (2014) Heavy metals in water, sediments and submerged macrophytes in ponds around the Dianchi Lake, China. Ecotox Environ Safe 107:200-206

Wetzel RG (2001) Limnology: lake and river ecosystems, 3rd edn. Academic Press, San Diego

Wu P, Yin A, Yang X, Zhang H, Fan M, Gao C (2017) Distribution and source identification of heavy metals in the sediments of a river flowing an urbanization gradient, eastern China. Environ Earth Sci 76:745

Wuhan Bureau of Statistics (2014-2018) Statistical bulletin of domestic and social development of Wuhan city in 2014-2018. Wuhan, Hubei, China

Xia WT, Xiao Q, Zhang YX, Wang R, Xin W, Guo CB, Bowker J, Chen YS (2018) Effects of aquaculture on lakes in the Central Yangtze River basin, China: III. Heavy metals. N Am J Aquacult 80:436-446

Yang YY, Wei LF, Cui LL, Zhang MM, Wang J (2017) Profiles and risk assessment of heavy metals in great Rift Lakes, Kenya. Clean-Soil Air Water 45:1-8

Zeng H, Wu J, Liu W (2014) Two-century sedimentary record of heavy metal pollution from Lake Sayram: a deep mountain lake in central Tianshan. China. Quatern Int 321:125-131

Zhang H, Shan BQ (2008) Historical records of heavy metal accumulation in sediments and the relationship with agricultural intensification in the Yangtze-Huaihe region, China. Sci Total Environ 399:113-120

Zhang L, Shao H (2013) Heavy metal pollution in sediments from aquatic ecosystems in China. Clean-Soil Air Water 41:878-882

Zhang W, Kong X, Tan G, Zheng S (2018) Continuous change detection of urban lakes in Wuhan, China using multi-temporal remote sensing images. Int Arch Photogramm Remote Sens Spat Info Sci 42:2315-2320

Zhang XZ, Bao ZY, Tang JH (1996) Application of the enrichment factor in evaluating of heavy metals contamination in the environmental geochemistry. Geological Science and Technology Information 25:65-72 (in Chinese)

Zhang YD, Yu JL, Su YL, Du YX, Liu ZW (2019) Long-term changes of water quality in aquaculture-dominated lakes as revealed by sediment geochemical records in Lake Taibai (eastern China). Chenosphere 235:297-307 
Zhang Z, Li JY, Mamat Z, Ye QF (2016) Sources identification and pollution evaluation of heavy metals in the surface sediments of Bortala River, Northwest China. Ecotox Environ Safe 126:94-101

Zhang ZY, Abuduwaili J, Jiang FQ (2015) Heavy metal contamination, sources, and pollution assessment of surface water in the Tianshan Mountains of China. Environ Monit Assess 187:1-13

Zhu B, Smith DS, Benaquista AP, Rossi DM, Kadapuram BM, Yu M, Partlow AS, Burtch NR (2018) Water quality impacts of small-scale hydromodification in an urban stream in Connecticut, USA. Ecol Process 7:11

Zsefer P, Glasby GP, Sefer K, Pempkowiak J, Kaliszan R (1996) Heavy-metal pollution in superficial sediments from the southern Baltic Sea off Poland. J Environ Sci Health 31:2723-2754

\section{Publisher's Note}

Springer Nature remains neutral with regard to jurisdictional claims in published maps and institutional affiliations.

\section{Submit your manuscript to a SpringerOpen ${ }^{\circ}$ journal and benefit from:}

- Convenient online submission

- Rigorous peer review

- Open access: articles freely available online

- High visibility within the field

- Retaining the copyright to your article

Submit your next manuscript at $\boldsymbol{\wedge}$ springeropen.com 